\title{
MARKET HUNTING IN NORTHERN IOWA
}

\section{Edited by JACK W. MUSGROVE}

The year 1918 saw the end of market hunting in Iowa, an occupation earlier followed by a large percentage of the population of smaller towns and throughout the state. Passage of game laws and aroused public sentiment grew too strong for the market hunter to carry on his activities. The market hunters are gone. Very few were the records left behind them. Only memories remained of the activity of a great number of men who gleaned a greater portion of their livelihood from the vast amount of wild life on the lakes and streams in early days.

Through the efforts of Mr. Fred O. Thompson of Des Moines, an interested sportsman, some records of market shooting activities here in Iowa have been collected. The following article, compiled from a group of interviews, deals with the experiences of Richard Harker, of Spirit Lake, Iowa, one of the early residents of Spirit Lake and one of the many who followed market shooting as a profession. This story was recorded and is told in his own words, for much of the history and character of the recital would be lost were it changed.

\section{- Richard HaRker's OWN STORY}

We came to the lake country in 1881. Garfield died the very day we reached Spirit Lake. I was eighteen or nineteen years old when I arrived.

The first year here I hunted for Winter; we hunted on the upper and lower Heron lake in Minnesota. The law was out then on the fifteenth of August on ducks. He hired about six men besides myself and his brother. We built boats out of ordinary lumber, peaked at both ends so we could push them through the rushes. We couldn't row in the lake, there were too many rushes. We used push poles. We built our cabin on the lower lake. It was about sixteen by twelve feet and we could all sleep to- 
gether in it at the same time with our feet together. We also had to built a barn for our two teams. We were located about two rods from the lake.

We would haul our ducks to Lakefield, Minnesota. Heron lake is about seven miles long. From Lakefield, Winter shipped most of his birds to Chicago and New York. Sometimes the New York and Chicago people used to come there and buy the game, pack it and ship it themselves.

Winter had a freezer. It was a building about fourteen feet square. You build a fourteen foot square in the center out of tight lumber. We put on a two by six border and filled the space with sawdust. Then we put on another two by six, left that as a dead air space, and then put on another two by six and filled that with saw dust, giving us a wall eighteen inches thick. Then, there were about twenty galvanized pipes filled with packed ice. He had an ice house and every day when it was hot he would go and break up three or four hundred pounds of ice as fine as he could and fill these pipes as full as he could, and at the top there was a door about eight inches thick that fitted over these pipes. They used plenty of salt and in a few minutes the pipes would show frost. We had two troughs to drain the water away. We had shelves built about eight inches apart and we could freeze a duck in there in one night as hard as a bullet. As the ducks would become frozen hard we pushed them back as far as we could get them. These shelves were made out of lathe so that the cold air could circulate. Some of the shelves were about six inches apart and some were about eighteen inches apart.

Winter would keep these birds until late in the seasonOctober or November. If he had his freezer full he would ship out his Blue Wing Teals and get a good price for them.

From the fifteenth of August until the time it froze up, old Dude ${ }^{1}$ used to kill about three thousand ducks. Dude

\footnotetext{
1 (Dude Gilbert) Fred Gilbert, Spirit Lake, one of the most widely known marksmen of his time.
} 
was the best man Winter had. He killed more birds than any of us. We all kept a record of how many we got. When night came we asked how many Redheads, how many Mallards, and so forth, we killed, and we kept a book account of every bird we killed. I have a brother that still has his records. I used to kill about two thousand birds from the fifteenth of August until the time it froze up.

\section{INDIVIDUAL SHOOTING RECORD}

This is an estimate of what we used to get when we were hunting for Winter:

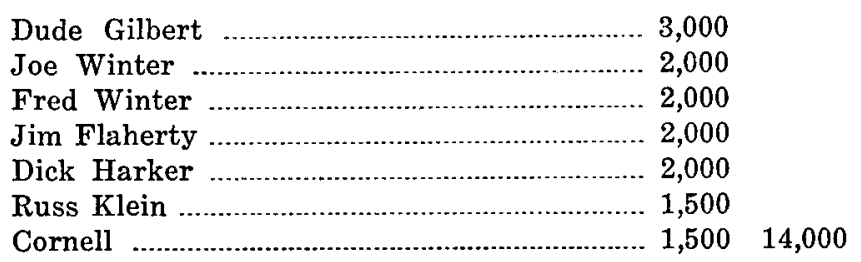

Whenever the cooler would get full he would sell out his Blue Wing Teal and he would get two to two and a half dollars a dozen for them sometime in September. Blue Wing and Green Wing, we had more of them than anything else. They used to get all the way from eight to ten dollars a dozen for Redheads, twelve to fifteen dollars a dozen for Canvas-backs, and six to seven dollars a dozen for Mallards. That was the price at the cooler.

Winter would ship about fourteen thousand ducks, plover, snipe and everything else to the market during the season. We didn't touch the birds at all when we put them in the cooler. We didn't cut off any part of them.

In the hot weather I used to go out in my boat and go in among the rushes and tie the tops of them together for shade and go to sleep for an hour or two.

I could sit here for a week and tell you fellows about the different kinds of birds I killed for the market. I have killed thousands of Golden Plover and Grass Plover. ${ }^{2}$ We used to get a dollar and a quarter a dozen for the Grass Plover and a dollar and a half a dozen for the Golden Plov-

2Probably refers to Upland plover. 
er. The greatest number of Golden Plover I killed at one time was fifteen from one flock. Of course, there must have been two hundred plover in the flock. We killed more Golden Plover than anything else. In about one month, one spring, I killed two thousand Golden Plover, Grass Plover, Curlew, Jacksnipes and Yellowlegs.

We used number nine and ten shot to kill plover. We loaded our own shells. Generally, it wouldn't cost us over a half-cent for the light load and a cent for the heavy load. We used brass shells almost altogether. The last year I hunted for the market we began to buy the loaded shells with black powder. We payed thirty-five cents for a box of twenty-five black powder shells. We used to use gold dust powder and this was powerful.

There were birds we called "Dowitch." 3 They were like a Jacksnipe, but they flew together in flocks of seventyfive to a hundred. At first we didn't shoot them because we didn't think they were good for anything, but after we found out they were good and we could sell them, we shot quite a few. We sold them to fellows from Chicago.

There used to be two species that we called Curlew. One that had a bill about eight inches long with a curl on the end and another with a straight bill about five inches long. ${ }^{4}$ I used to be able to call these birds just so that they could hear me and I could hear them.

We had two kinds of Yellowlegs, ${ }^{5}$ the large one and the small one. The Yellowleg was another bird I could call as far as they could hear me. Whenever you would call them and you would shoot one of them the others would hang around and you could call them back, and keep calling them back until you cleaned up the whole bunch.

There used to be a Dow Bird. ${ }^{6}$ They were a good deal - like a Woodcock, but they were of a different color. They were mighty delicious meat and were soon extinct. I didn't kill more than a dozen or fifteen of them in my life.

${ }^{3}$ Refers to Dowitcher.

${ }^{4}$ Refers to Godwits and Willets.

${ }^{5}$ Greater and Lesser Yellowlegs.

Eskimo Curlew. 


\section{Hunters ON SALARY Basis}

Winter paid us seventy-five dollars a month and furnished us with everything: food, shelter, shells, everything except our guns. This was for both spring and fall shooting.

At Loon lake, ${ }^{\top}$ one week, I killed enough Redheads and Canvas-backs to pay my salary for the whole month. Loon lake is still good Canvas-back and Redhead lake.

My brothers and I studied the ducks and never used a duck call. We used our voices. Even to this day, I can call a Mallard to a fare thee well.

My brothers and I shot for the market ourselves. We built our own cooler on our farm on the west side of Miller's bay. There were three of us-two brothers and myself. We were all good for about three thousand snipe and plover. We killed them in about one month. We'd start in May when people were seeding and the grain was just coming up. When they burned the prairie grass the snipe $^{8}$ would go to these burned spots and feed on the bugs and worms.

My brothers and I shot for the market for fourteen years. We had two coolers, one at Kandiyohi county, Minnesota, and one on our farm. We did quite a bit of shooting in Kandiyohi county. We shot on what they called Long lake and Slit lake and on what they called Mud lake near New London and also on Green lake, which was almost as large as Spirit lake. Green lake was the playground for the ducks. They went there for protection.

I killed forty-eight ducks one night, after sundown until dark. I didn't pick them up that night but went back and got them the next morning. This was a big rice lake. Any day when the wind blows hard the ducks will leave this big lake and will fly to the smaller lakes where they feed. This is why the hunters like a windy day because the ducks don't like to stay on rough water.

Winter had pump guns away back in the 80 's, long before I started to shoot for him. They were Winchesters

TLoon lake, lake in the southern part of Minnesota near the Iowa boundary.

${ }^{8}$ All types of shore birds except plover. 
and Spencers. We had a Spencer pump gun in the 80 's. We used to have an old lever action pump gun that would hold six shots. The Spencer's action was like the Winchester action now is only they didn't lock. I have had lots of miss-fires that way.

Henry Winter shot a Spencer all the time. I had a Smith double barreled ten gauge hammer gun. Old man Winter had a Smith gun with Damascus steel barrels.

I began shooting with a pump gun the first year I hunted for Winter. I also had a double barreled gun. I let Dude use that gun and he could shoot birds further with it than any gun he had. I think Winchester made that gun with the lever action. This was about ' 87 or along in the 90 's, because it was about ' 87 or ' 88 that I started to hunt for Winter. I got my double barreled gun to shoot chickens ${ }^{9}$ with. Henry had a Baker, Joe a Smith, and Dude had an old time Parker: This Parker was the best shooting gun I ever saw.

\section{DUDE GILBERT'S SHOOTING}

Old Dude went up to Heron lake. ${ }^{10}$ One time a fellow by the name of Charley Hamilton was a guide there and had a bunch of fellows from Chicago out. Dude came along and stood behind these fellows. Two or three flocks came by with about seventy-five or a hundred ducks and these hunters fired at them and they would scratch one or two. Then one of the hunters turned to Dude and said, "Say, young fellow, did you shoot?" Dude said, "No." Then this fellow asked, "What's your name?" "My name's Gilbert," Dude said. "Well, I've heard about you, why didn't you shoot?" Dude said, "Well, I don't like to shoot over another man's decoys," and they said, "Well, you shoot the next time." Dude said he'd shoot after they got through shooting. It wasn't long until another flock came along and he waited until they got through shooting and then he got a pair. They asked him what shot he was using and he said he shot fours. They were using twos.

Prairie chickens.

${ }^{10}$ Heron lake, a southern Minnesota lake. 
After that they used fours, and they thought he was quite a hunter. They asked him how he could kill them with fours and he told them, "The way you fellows are shooting close up, I could kill them with sevens."

There's one place up there that still goes by the name of Gilbert's Hole. He was pushing along in his boat one day and fell out in the mud and made a hole in it. This was in lower Heron lake where Dude shot all of his Mallards.

On either one of the Heron lakes we had natural blinds. We just pushed into a bunch of rushes. The rushes were as high as your shoulders. We had to break the tops of the rushes before we could shoot. We didn't tie our boats. Other fellows used to do that. Our boats were possibly ten or twelve feet long and thirty inches across at the bottom of the boat. That made a good steady boat and it came to a peak at both ends. We made a cover at both ends of canvas or tin to put our ducks under. We never had any oars, we just pushed these boats about. The material to build these boats didn't cost more than two or three dollars. We built them ourselves. We used a kind of yellow pine.

We never used any dogs to retrieve. I could beat any dog in retrieving. We wouldn't let our ducks lay long; nor let them get watersoaked. We used to be able to drop a Mallard and let him go for a quarter of a mile and go straight to it. I could beat the world today retrieving ducks. We just learned that by shooting. The first thing I do is look for a mark ahead of me and back of me and just judge the distance and keep a going: On a slow day when the ducks weren't flying, old Dude used to be the best of any of us. We'd push around in the rushes and do what you would call jump shooting and we'd kill thirty or forty in an afternoon. We had a cross piece on the top of our boat and we put our trigger guard down on that and the barrel was on the floor of the boat and when ducks would jump up we'd let the pole go and shoot at the duck and kill it and then take our little paddle and go back for the pole. I did that only last year. 


\section{Minnesota Required Hunting LiCenses}

When Iowa didn't have a license law and Minnesota did have one, they couldn't charge us for any license. This was along in '95 or '96. We had been hunting up in Minnesota. They didn't like us very much and they threatened to mob us several times. They were hunters from Minneapolis. They didn't like to have us up there. Old man Cobb told us: "Boys, if you go to Minnesota this year, better get a license." He said he noticed that Iowa had passed a license law and that we'd have to get our license from Minnesota. It was right on the last day. We had about seventy-five ducks, a team of horses and a wagon. A fellow came out on Sunday. We never hunted on Sunday. This fellow came out to where we were stopping and we had a funny feeling that something was wrong; it came over us just that way. This fellow was there practically all day. They came out in a rig, two of them, and they never said anything. We went into the house and we were singing. We were quite a hand at singing. They wanted to sing with us, but we didn't have any pep. Finally we asked who these two fellows were. They had threatened the fellow at the place where we were stopping not to tell us who they were but that they were there seeing him. This fellow told us that they had no warrants for us.

Monday morning the dog began barking and there were these two fellows. One of them went into the house and loaded his revolver and the old lady asked what that was for and he said, "Sometimes the law requires us to have it." These men asked, "Boys, do you have a license?" We said , "No," and he said, "You are all under arrest." Then he said, "We'll have to take you to Wilmer." There were only two of us and he asked. where the other fellow was and we said he was up in bed.

Just before he took us in the rig the fellow at the place where we were staying said, "I am going to buy your team. They will take your team of horses." I said, "All right," and he said, "I will give you a dollar for them," and we said, "All right." After I got into the wagon the head game warden said, "By the way, you got a team of 
horses here ?" I said, "No, we just sold them," and he said, "Whom did you sell them to?". and I said, "None of your business."

They took us to the justice at Wilmer and we plead guilty. He fixed up our fine. I think they fixed it at three hundred dollars, and I said, "How can you do that? The law says fifty dollars for the first offense." They went right back and came back with a fine of fifty dollars a piece. They took all our guns. We turned in our decoys and we got a good price on them. They gave us twenty dollars apiece for our guns. You could buy a new gun for eighteen dollars and mine was three or four years old then. In those days they took our goods and stuff in place of money. Amongst the three of us, we had to dig up thirty-five dollars. We had Mud Hen decoys, Mallard and Canvas-back decoys and we turned them in for four dollars a dozen.

The reason we used Mud Hen decoys was that the Mud Hens ${ }^{11}$ fed with the ducks. We had the Mud Hen decoys mixed with the Mallards and Canvas-back decoys to make the stool look natural. In those days we didn't use the word stool, we used the word bunch.

\section{Commission Houses the MaRket}

It seemed, when we were market hunting, that every year ducks were just a little harder to get. When we hunted for Winter we worked hard, but when we hunted for ourselves we took more time off. We shipped our birds to Chicago and New York. Sometimes they would come out to buy them, but most of the time we shipped them out by express; and express was high in those days. We shipped them to commission houses.

At one time, up in Minnesota, when we were hunting for the market, my brother, Frank, and I came down on what they call Grass lake and about a quarter of a mile ahead of us we saw something that looked peculiar to us; it was spotted. The more we looked the more we thought it was funny, and then we saw the wings flutter and it 
was nothing but Green Wing Teal and there were possibly three or four thousand. The wind was just blowing right to the shore and it was the best place in the world to get them. We had to shoot through the flock. We both had double barreled Smith guns. I said to my brother, "Are you ready ?" and he said, "Yes," and I said, "Let's give it to them," and we raised up and I didn't hear his gun go off, and then it finally went off. He had had his gun on safe. He got a few. I killed thirty-seven.

At Heron lake we would snieak around and shoot into the ducks when they were sitting in the water and would kill eight or ten at a time. I would kill three or four sitting and the rest when they got up.

This was in the spring of the year when we were living out on the farm. One spring the Redheads were feeding in the bay, coming over a big chunk of ice, and nobody knew how to get them. They were lying so far out that nobody could get at them, but we figured out a way. There was a big chunk of ice that was too big to go into the bay. These ducks came in and sat on the ice so far from the shore that we couldn't get at them, so we took our boat and went out to the ice. We tied thirty decoys to a long anchor rope. We then went out to the ice, about a quarter of a mile, and took a couple of sacks filled with straw and covered ourselves with sheets, and these ducks would come over to the decoys and we would sure cut them down and we never picked any of them up because they were floating right in to shore. We shot that way for several days and killed several hundred.

One day when we were hunting we noticed that all at once our decoys were floating away from us. This ice wasn't so good; it was rotten. The decoys were where we had put them but our ice had broken and was floating across the lake. We had our boat with us, so we took it, picked up our ducks, and went after the decoys. That stopped our shooting. We were lucky we had the boat with us, for without it we might have drowned in the middle of the lake. 


\section{Ten Cents Apiece for Blue Bills}

In the spring of the year I saw a lot of Blue Bills feeding near shore. I took a dozen decoys and put them out about twenty yards from the shore. The wind was coming from the northeast into shore. I had a little double barrelled Smith gun and was shooting all kinds of shells; anything I could get hold of. I went down a little ways and put out my decoys. I never had a blind, just got down on my knees. They came in so steady that I never got off my knees. I don't suppose it was more than an hour or two when my father came along and picked up those ducks. They floated on to a little sand beach. I saw him pick them up and put them in piles. He had a half dozen piles, and he came along and said, "How many ducks do you think you have?" I said, I thought I got pretty close to a hundred and he said, "Well, I picked up just an even hundred Blue Bills." Then my brothers came over, but they had quit coming in. We went to Gull Point ${ }^{12}$ and I killed twenty-five more Blue Bills and my brother killed that many, so we had one hundred and fifty for the afternoon. We shipped these to R. E. Cobb, at Minneapolis, and he gave us ten cents apiece for them.

In the fall of the year when Dude would get through hunting for Winter he would come out to our place and we always had good shooting on West lake. ${ }^{13}$ It stayed open a long while. For about two or three weeks we'd average a thousand birds a week; just Blue Bills, Canvasbacks and Mallards.

We used to get a dollar and a half a dozen for Saw Bills, ${ }^{14}$ Blue Bills, Whistle Wings, ${ }^{15}$ Butterballs ${ }^{16}$ and such like of that. Lots of people didn't like the fish taste of Saw Bills. In the fall of the year we got a dollar and a half a dozen for them and in the spring of the year we got ten cents a piece for them, that is for a mixed bunch of ducks.

${ }^{12} \mathrm{~A}$ point on West Okoboji lake.

${ }^{13}$ West Okoboji.

${ }^{14}$ Mergansers, fish eating ducks.

${ }^{15}$ Goldeneyes.

16Buffleheads. 
We made about seventy-five to a hundred Saw Bill decoys. They were just as natural as life. They were the prettiest looking sight you ever saw in the water and the Saw Bills would just fall into them. In the morning we could go out and kill from seventy-five to a hundred Saw Bills.

We made ourselves and used the following decoys: Mallards, Canvas-backs, Redheads, Blue Bills, Saw Bills, Mud Hens.

Anything will go into a Mud Hen. You can mix them in with any kind of decoys. A buch of ducks will see a bunch of Mud Hens and will go over into them.

We had a little tool house on the farm and we put in all our spare time in the winter making decoys.

SPORTSMEN RESENTED MARKET HUNTERS

We were hunting at Long lake in Minnesota, and they were mad at us and would keep tab on us and see how many ducks we shot, and then talk among themselves of how many ducks these Harker fellows had shot.

One night when we got through hunting we thought we'd hide our boats in the rushes. They found our boats that night and had an axe with them. We had a little strip boat that had been made by a boat builder. They took a couple of swipes and cut her wide open, then went to our other boat and took rocks that weighed three or four pounds and smashed it up for us. We didn't know who did this, but they were fellows who didn't like us. They were sportsmen from Minneapolis. They didn't want us there at all, because we could shoot and they couldn't hit anything.

The boats were completely ruined. We built some more right there. They couldn't drive us out.

They were ready to mob us one night. We didn't hear of this until some time after, but there was a gang all ready to mob us but they never undertook it.

One boy, some little fellow, took a shot at us. I didn't know whether he was shooting at us, but he was shooting a "twenty-two" rifle. This was done for spite work all right. 
This was at Long lake, right north of Wilmer. I was shooting there and my brother was at the point. I had some ducks and was killing quite a few. I had pulled my boat around a rat house and all at once $I$ heard a racket and I looked around and there was a farmer; they were all Swedes and Norwegians up there. He had a four tine pitch fork and was sure mad at me and told me to get out of that lake. I told him, "You poor old fish, what's the matter with you? You don't own this lake. This is government water and I've got a perfect right here." Then he was going to have me arrested and I told him to hop right to it, that I was going to be right there at the lake. He called me everything he could think of and I laughed and made him all the more mad. He couldn't get at me because I was out in the water.

We all have been chased, when we were in the fields chicken shooting. Farmers would chase us with pitch forks and monkey wrenches and anything they could get hold of. We were all like greyhounds and by the time anybody could get to us we would be far away. We could go just like a jack rabbit and they could never get us. They would chase us because we were on their farms.

\section{Game LaWs DisREGARDED}

They tell a good one on me. It happened fourteen years ago. I was hunting at Jemmerson slough one spring with Elmer Mills. There were quite a good many ducks. I was shooting in a low place between two points. After a bit I looked toward town, I always had a funny hunch when somebody was coming along, and saw something bob along and it looked like a man's head and I decided to watch that man figuring he might be a game warden. When he got to the gate where you go in the sloughs he came right in. My friend, Mills, had a few ducks killed. The warden came to where our cars were parked and looked into them and took out his pencil and wrote something down. I had some ducks and I took them out and shoved them under the grass. He talked to Mills and asked him what luck he had been having. Mills said he had pretty good luck and 
he asked him for his name and for his license. He said he was a game warden, and just got his man, Mills,- he just wilted. He got another fellow and asked him if he had any ducks and this fellow said, "No," that he didn't have any. This fellow was wise enough to hide his ducks.

Then he went to another fellow and just before this game warden came over he killed a pair of ducks and he asked him for him name. It was Frank Wright and then he told Wright he was a game warden. Then he asked, "Who is that fellow over yonder, shooting?" He said it was a fellow from town, and the warden made a straight bee line for me and I said to myself, "If you get this one, fellow, you are going to be a good one," so when he started for me I went in another direction where another fellow was shooting and when he got to where I had been I was as far from him as I was at first.

There was a farm house just outside of town and I changed my clothes there. I thought he'd come after me and lay for me. I came into town and had on different clothes and had on a Stetson hat, 'and walked right into the house and my wife said, "Mr. Harker, why, what is the matter?" I said, "Nothing." Finally, when I told her I was getting away from the game warden we all had a good laugh. The farmer brought my hunting clothes the next day.

The game warden stayed at the Antlers Hotel for a few days and came into my store and asked my man if I was in and that he wanted to see me. I had told my man that if this fellow came in to tell him I was out. He told my man that he wanted to see me and that I should come down to the hotel. Well, he'd have to wait a long time for me to go to him at the hotel.

When I would be walking through the streets the boys would holler, "Look out!" "He's right across the street, Dick." Well, one day he was walking up the street and I guess we passed and somebody told me that it was him, and nobody said a word, and I left town.

It even came out in the paper and they said that the last they saw of me was that I was going through Emmets- 
burg and said that I ran into a few jackrabbits and told them that if they couldn't run any faster they should get out of the way, and I kicked them out of the way and told them to let somebody run who could run.

\section{MARKet HUNTING SINCE 1881}

I came here in the fall of ' 81 and hunted for the market. My brother and I hunted with Dude. We boys knew the different kinds of ducks just as far as we could see them. I'm not boasting, but I'll bet there isn't a man in the state who can tell ducks better than my brother or I.

In the spring of the year, at Gull Point, on the west side of Okoboji lake, the ice had broken up but there were several hundred acres of ice left. The wind came up from the north and pushed the ice up on to Gull Point and it piled up about twenty-five feet high. We put out our decoys and built us a blind. There were three of us sitting there on sacks of straw. A flock of twelve ducks came by and lit in, we all shot pump guns, and we commenced to shoot. My brother John kicked a piece of ice which came down and we were jammed in, but we kept on shooting till we got all but three or four of the ducks.

We used to go out every morning in the fall. There were lots of geese on the lakes. When night would come we loaded our shells. I happened to have a Spencer gun.

One morning I went to Emerson's bay and my other brothers went to Gull Point. As luck would have it, as I was walking along looking straight toward the lake when I heard a noise and said to myself that it must be geese and they have heard me but didn't know where the sound was coming from. I dropped down to my knees and as I was going to get up they came right at me without making a sound. I just laid there until they were over me and I got four of those big boys. I could have gotten six of them if my shot had been bigger.

Another day, I killed six geese in a peculiar way. I was at the house and knew where there were two geese. I decided I was going to get them. I took my pump gun and had in five loads of 4's and two loads of double 00's. 'I 
looked over the hill and I saw the geese going up ahead. When I got up to a little swail, there they were, but instead of two there were ten of them, and I hadn't seen more than two. I commenced shooting at them and killed six. I got four of them and two drifted away from me.

Late in the fall there were about five or six hundred geese on the lake in different spots. At night the geese came down to the point in Miller's bay. We could hear those geese fighting and scrapping. We had four guns; all Winchesters. We got up early in the morning to milk our cows, but didn't use our lanterns because if the geese saw the lanterns they would go. Then we started for the geese. We didn't have to go more than a quarter of a mile. We laid down on the ice on our bellies and crawled along and the best we could do was to get within fifty or sixty yards of them. We waited until it was light before we started to shoot and then I noticed my two brothers about four or five rods to our left. We waited until they could get away and then we commenced to shoot. We got seventeen geese and they got twenty-four. We killed them all at about sixty or seventy yards.

In the spring of the year, my brother and I thought we'd go to the head of the lake and shoot there. When we got to the head of the lake we found two other fellows. Well, we came along there and right at the head of the lake there was an open space in the ice, possibly thirty rods from the shore. There was some ice lodged there. A flock of Canvas-backs. was feeding about twenty feet from the shore and as anybody came along they would go out into the lake. We took out twenty-five decoys and hid our wagon. We put out our decoys and then waited for the Canvas-backs to come back. They started to come and we weren't shooting more than two hours and killed about seventy-five. Ed. Wilson was shooting along there and said, "You fellows have a lot of gol-darned luck. Here we've been shooting all day and got only ten ducks and you fellows have got so many in such a short time." We told him, "Well, we know how to hunt."

We used to get thirty-six dollars a dozen for Canvas- 
backs. This must have been along in the nineties. The ducks would have to weigh so much to bring that price. We surely made a great killing that day.

In the fall of '86, Cornell, Quinell and I went over to Lakeville where that chain of lakes is. We went into a vacant house there, apparently the grasshoppers had driven the people away, and we stayed a week. Those fellows were both crack shots. That time we shot three swans and I forget how many geese. We got Sand Hill Cranes and ducks enough so that when we came in we had a wagon box well filled with game.

\section{COMING OF THE RAILROADS}

The nearest railroad when we came here was Marshalltown. I was one of the appraisers at the time the "old B. C. R. \& N." (Burlington, Cedar Rapids and Northern) built their railroad, and we appraised that land at fifteen dollars an acre. I appraised the land from Sibley to Estherville.

When I went into business here, I hauled all my goods from Sibley, about thirty-five miles from here. When the Milwaukee Road went through Spencer, I hauled from Spencer. At that time it was called the Southern Minnesota. The Milwaukee Road didn't intend to build up here until the B. C. R. \& N. made up its mind to build a line to Estherville.

We were anxious to get some road up here, and so we voted a tax for the B. C. R. \& N. people. When the Milwaukee people found these people were going to build that line they built one too and so we got two roads.

There was a man here who claimed pretty near this whole county. He claimed it under the Swamp Land Act, and to keep other people out from the best part of the land around the lake shores he plowed furrows for miles around and then all inside of that he tried to keep everybody out of. He claimed the whole of that enclosure down there where Arnold's Park is now. That was a fine piece of timber for this northern country. We got a portable 
saw mill in some manner and built quite a nice house where the Arnolds Park Hotel is now.

There was lots of oak, basswood and elm here, but no walnut, but there was lots of walnut at Estherville and down on the Sioux river.

Regarding this man who tried to claim all this land, it got to be where the people thought he was a hoax and they began to settle in and finally, by George, they ran him out.

This man tried to hob about twenty-five thousand acres of land. Nobody liked him at all. He would go out on trading expeditions and would trade this swamp land for anything he would get and one time he came in with five or six wagons loaded with groceries and he was trailing in a lot of jackasses. He turned them loose in the winter and let them pick up their own food.

When my brother-in-law was auditor of this county, he said he was looking up a piece of land. He had traded for a piece of land and they located it right in the middle of Spirit lake.

The Indian outbreak was so bad out west that father decided not to go to California, so he traded his house and lot for a piece of land up at Spirit Lake and this fellow couldn't deed it to us so we had to homestead it. Taking in the lake shore and all it was 172 acres. We owned the whole west shore of that little Lake Minnewashta.

We came across the country with a dozen other families. At that time there wasn't a bridge across the Mississippi. We had to ferry at Dubuque. We came in prairie schooners all the way.

\section{MASSACRE AT SPIRIT LAKE}

The massacre here at Spirit Lake, at Arnold's park, was in 1857. The Indians killed thirty-two. There was a man out in the morning hunting cattle. The Indians had come as far as Jackson. When he came back to his cabin he found his family all killed, except his two children, his baby and the next one. He brought them across from Jackson to our stockade. Of course, we were well protected then. That is how they found out that the Indians 
had come that far north. Then they got what few men could be spared and they went there to bury the dead and take care of what few were left alive. I saw those children brought in.

I often say I was the only person in this county that got blood drawn during this massacre. They drove a spike in a two by four and they kicked it over and it fell into a hole. The prongs of the spike ran through the heel of my foot. I will never forget that. Sometimes I can still feel the cords of my foot draw up.

Those were the Sioux Indians. They hung thirty-eight of them up at Mankato. My father saw them hung. They gave the Indians a regular trial, the same as a white man. They built a special scaffold and hung all thirty-eight of them at the same time. I had a picture of them. It was snapped at the time they had the ropes around their necks. They built this scaffold so that they could hand the whole bunch of them at the same time. They put the ropes around their necks, let them smoke the pipe of peace and use their devilish language. I suppose the Indians did this for safe-keeping and to carry them over, and then they pulled the chute. One old fellow broke his rope and came down and they had to put him through a second time.

The scaffold was built in a square and it was probably the size of this room, and the frame that the ropes were fastened to was about as high as this room. They had it so they all went down at the same time and they got them all except this old fellow. These Indians had their hands tied behind them.

I have seen this country grow from the prairie grass to what it is today. You could go from here to the Black Hills and not see a person.

We used to have to fight prairie fires very often in the fall. Charley Sternaman, who used to run a pool hall here, his father burned to death while they were moving from Estherville here. We often used to go out on the backline before we could break a fire up. The prairie fires destroyed the property of quite a few of the men here in town. 


\section{Goose Shooting}

My brothers John and Frank, and myself went down to Emerson bay and found the geese were feeding on the fields out west. We got there in the morning and killed three of them, proving that the early bird always catches the worm when you are hunting. We all used pump guns and we scattered along the beach. As luck would have it, there was a flock of geese that came over my brother John about sixty or seventy yards up and it was a pretty sight. My brother always liked to have them straight over him. He killed three of them. That ended that hunt. The geese all went out and we didn't kill any more that day.

I killed nine Brant ${ }^{17}$ one afternoon. I knew that they were feeding in a certain field. It was in the spring of the year. In that cornfield there was about seventy-five Brant. I hadn't been there long until those Brant started coming. It was a still day and they came out to the cornfield and circled around and around several times and finally lit. They lit about thirty rods to one side of me and started to feed. I sat still and they went up a little bit north of me, just flying over one another and feeding. It seemed like they were trying to get ahead of one another and then they happened to turn and come by me. They came within forty yards of me. I was shooting a Winchester pump gun with number four shot. I killed six of those Brant and the last one I killed was white. ${ }^{18}$ It was the only white one in the flock. When I picked them up and started for home, I heard some Brant coming and I saw two of them coming over the lake. As a general thing if you kill their mates they come back after them. Well, those two Brant came after their mates, but they were too high, so I couldn't shoot. Finally they left. Pretty soon they came back and circled around a little lower, but I didn't shoot. Finally, they left and came back again, and this time they came low enough and I got up and killed them.

\footnotetext{
${ }^{1}$ Refers to any species of small goose such as Snow, Blue, and Whitefronted geese.

${ }^{18}$ Snow goose.
} 
Well, I had those Brant to carry about a half mile. They weighed about eight pounds each. They were the speckled breasted Brant.19 Then I saw my brother on the road and to hail him I shot my gun off and he looked around and stopped.

At the same time, my brother went to a lake we called Rush lake. He saw some swan enjoying a swim and killed six of them.

\section{Brants Followed Dead Mates}

One spring, while on the Sioux river, I was all alone and had only about thirty shells with me and I had to make every shell count, and I saw a place on the Sioux bottom where there was quite a pond and a good many ducks lighting and a big snow drift on one side. I had four or five ducks that I had killed and I worked around to this snow drift and put out my decoys and made a blind in the snow drift and sat down there. I killed twenty-four ducks and one Brant. I was about three miles from home and packed those ducks all up and put them on a string and started for home. I had one shell left and it got pretty dark, but I got home. I was within a mile from the house and I heard some Brant coming, so I just squatted down on the burnt prairie. I couldn't see them but I would hear them. They were some thirty-five yards along side of me and they were so thick I could just see a black mass. I took one shot at them and I killed four of them. They were just a common Brant ${ }^{20}$ and weren't good, but I carried them home. On my way home, two of those Brant followed me clear to the house. I couldn't see them, but I could hear them. You see, I had killed their mates. Of course, that is the nature of the brutes in the spring of the year, when you kill the mate of a Brant or a Goose they will follow you.

Years ago, when we hunted for the market, Gilbert, my brothers and myself would hunt until the fellows that we hired out to got through with us and then we would go

10Whitefronted goose.

so Blue goose. 
home to the West lake and that was just the time that the Saw Bills, Blue Bills and Redheads came from the north and stayed in the West lake because of its being open. We used to go up on what we called Sand Point and we would average just about a thousand ducks a week in about three weeks and they were mostly common ducks; Blue Bills, Saw Bills, a few Redheads and Canvas-backs mixed in with them. That surely was great sport.

We made some great chicken ${ }^{21}$ hunts from here to Clay county. We used to kill most of our chickens in the cornfields; four of us going abreast, jumping them. We used to leave early in the morning and go south into Clay county and leave the next day for home in the spring buggy we had. We used to kill enough chickens to fill our buggy and we often had to hold our dogs in our laps. We used to kill possibly two hundred chickens and they were just piled up in the wagon. We used to make these trips twice or three times a week and we always killed just as many as we could hold in our buggy.

Once I saw Joe Winter over at West lake and the ducks were flying so thick that he got the fever and he couldn't hit them at all.

\section{Shooting Geese at Feeding}

In the fall of the year when I came home from the north, my brothers and I had been hunting up in Minnesota, and I started to hunt chickens. I was shooting for the market and I was killing twenty-five to thirty a day, and coming home one night out west of Okoboji lake I ran onto a big bunch of geese feeding on the barley field. I didn't scare them up, I just let them alone. I started. home and on my way home, it was getting quite dark, and I was expecting them to go to the lake, and I looked around and noticed a flock of about a dozen coming behind me. I was driving the buggy and I stopped the horse and ran about fifty yards from the buggy and they came off to one side and I killed two of them. I knew that wouldn't scare those on the field. I was going to wait a couple of

¿Prairie chicken. 
days until my brothers came home so we could make a good killing.

One day I was out and happened to come across these geese on a field way south of where they were before and I thought that somebody had been into them. Later I met Ed Wilson and Elmer Henshaw hunting chickens and I asked them what luck and they said nothing much and I asked them if they had seen any geese and they said they hadn't, and I thought they lied to me when they said, "No," and they did. I said to myself that those fellows had found the geese on the field and if they beat me in the morning they're pretty good.

I had a bunch of geese decoys that I had made and the next morning I got up at three o'clock and took my decoys and horse and buggy and started for the field. It happened to be a bad foggy morning so the geese couldn't see the decoys, nevertheless I got to the field early and put out my decoys. The stubble was partly burned and I laid down on a piece of ground that was burned and put some weeds around me and got within fifty yards of my decoys. At daylight I thought I heard a goose and sure enough there was a dozen that laid down about a hundred yards from me. They never saw the decoys, but they saw them after they lit. My only bet was to crawl toward them on my belly and I crawled until I got up within fifty or sixty yards of them and they got up. I got up and shot at them and killed one, just winged him, and ran to get him and while I was running to get him the same flock turned right around and came over me and I killed two more of them. I went back to my blind and pretty soon I heard the other flock coming. There were about seventy-five geese altogether that fed on that field. I could hear them, but couldn't see them. They circled around the field several times and finally lit about a half mile north of me. I just sat there and waited and they were scrapping and fighting; I could hear them.

Finally, two prairie chickens came just a few yards from me and I made up my mind that those chickens were worth as much as a goose, then I changed my shot and put 
in some No. 5's and killed the chickens. Then the geese got up and went away to the north and finally it seemed as though they were getting closer, but it was so foggy I couldn't see them. There were about fifty or sixty of them. I had heavy shot. I shot three times and killed three geese. They fell right around me. I picked my geese up and they were so heavy that when they struck the ground they sank in about four inches. I went on hunting chickens the rest of the day.

The morning after that I saw Ed Wilson and Elmer Henshaw and they were coming to get those geese. They had figured on going for those geese the day before, but didn't go because of the fog. The next day they came out there and set up their blinds and the decoys and the geese came but they flew so high that they couldn't get them. The geese made a few squawks and went right over that field. Elmer said, "There's something wrong here, I'll go around and see if somebody has had a blind here." $\mathrm{He}$ went around and the first thing he said he saw was some weeds and it looked as though somebody had crawled along the ground and there were two holes in the ground where the geese had fallen, and he said, "It looks like Dick Harker has beat us to it."

About three o'clock in the afternoon, I met Henshaw and Wilson and they drove up to me and stopped and I saw they had geese decoys in their wagon and I asked them if they had any geese located and they didn't say a word, and then Wilson jumped out of the wagon and he said, "You are the darned old fool who got into those geese," and then I laughed and told them I had killed six geese. I told them when I met them the other day I knew they had found those geese. I told them that I found those geese a month ago and I wasn't going to let anybody beat me to it.

My brothers Frank and John had killed seventeen geese on that field a year or so ago. They were out hunting geese and found them on this field. The next morning they got up early and went out, dug a pit and covered it with a black Galoway robe, and they put out their decoys 
and then a flock of geese came in and they killed eight of them and then another flock came in of three or four and they killed them all, and then finally there was another flock, and they were both under the same robe, and there was about a dozen in that bunch and Frank said to John, "I'll tell you when to shoot," and so he left it up to my brother to tell him when to shoot, and then the geese swung around and he said, "Shoot, John," and he turned the robe over so it fell over John, and he killed three of them. John finally cleared himself of the robe and then he shot three geese himself.

\section{WILLING TO DIE AS HE HAD LIVED}

"One of the most outstanding events in my life," writes Dr. John H. East of Denver, a member of the Colorado State Historical Society, "was in attending Col. W. F. Cody-Buffalo Bill-the bravest man I ever saw die. When asked if he would like to see a minister, his reply was, 'I am willing to die as I have lived-on the square.' He was a good friend of mine. I asked him when taking his chart history how old he was. His reply was, 'seventytwo, and two hundred years in experience.' I held his hand in death and, as he passed away, he held my hand, raised his head and, looking into the future, lay down and passed over the range."-The Colorado Magazine.

\section{POLITICAL EQUALITY IN IOWA}

At a meeting of the Iowa State Teachers association in Marshalltown in 1869, Prof. T. S. Parvin "called attention to the fact that in 1857 the Association resolved in favor of woman suffrage." Also at a meeting of the Iowa Press association in Keokuk, the same year, J. L. McCreery, a famous Iowa poet, read a poem on the subject, the closing paragraph being:

So the conflict goes on, betwixt might and the right, But even today the assurance grows bright. That in ages to come, as in centuries past, Injustice shall fail, and Truth triumph at last. 
Copyright of Annals of Iowa is the property of State of Iowa, by \& through the State Historical Society of Iowa and its content may not be copied or emailed to multiple sites or posted to a listserv without the copyright holder's express written permission. However, users may print, download, or email articles for individual use. 